\title{
號七十四百二第
}

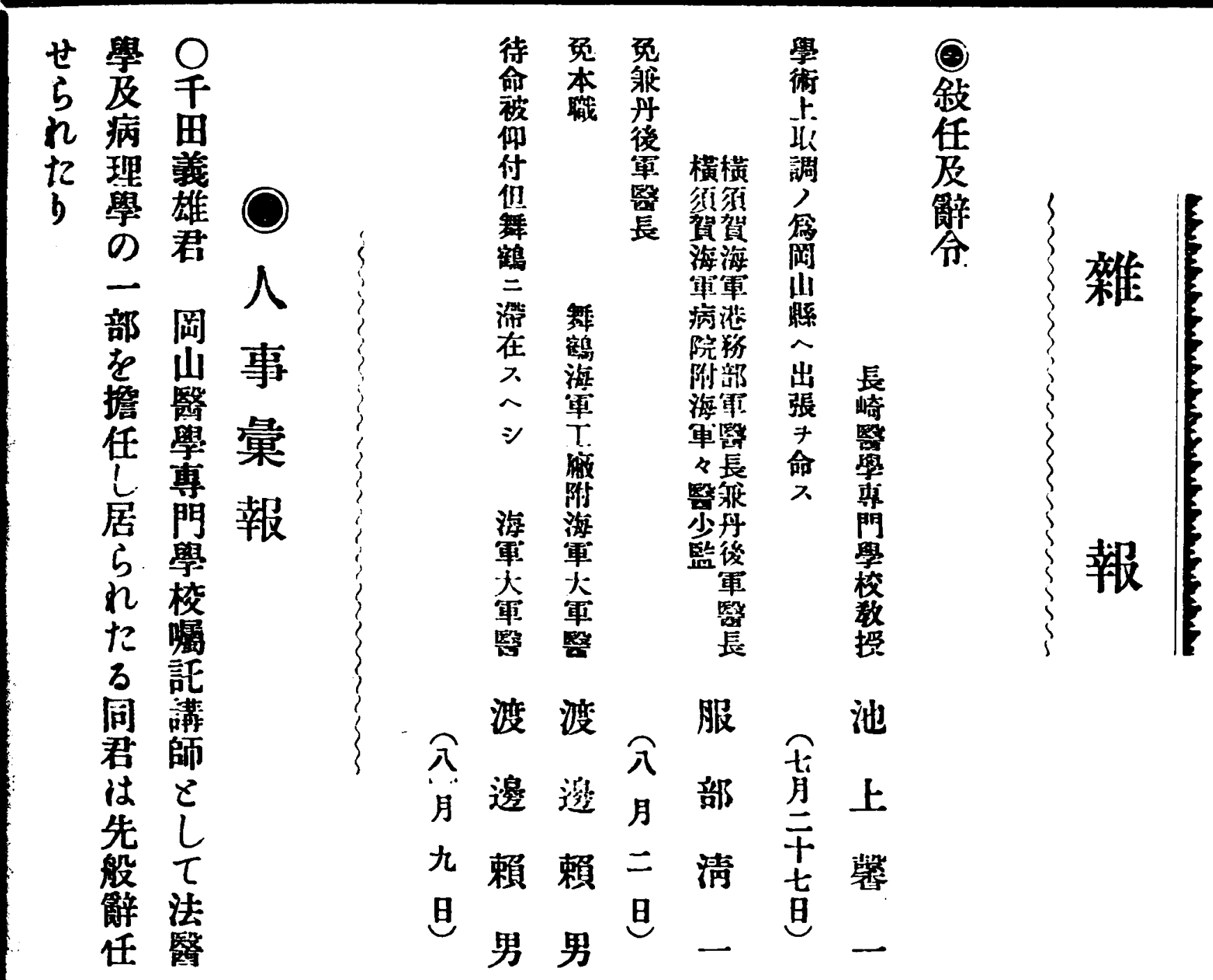

歸病○國○於於 $\bigcirc b$

鄉院渡東根元传

也眼邊佰 鈴開 研野

与科守郡勝業究又

几に衛下太せ中新

た勤君 北郎 らな君

b 務焂君方方

しは 村

居昨には

年於去

n 岡 $\tau$ 月

ᄂ.山 開 上

品醫 業 b

病學世”大

氣專 阪

の門的问

雼學 生

め校 b 病

去卒院

月 業

中 後

旬 岡

鲫 山

辅
たしは

加筆

今 $\tau$

般 京

歸 都

郷 醫

松 科

江 大

市 學

津 耳

田 鼻

街 洏

道 喉

西 科

丁 教

目 室
出 $\bigcirc$ 當術 $\bigcirc$ 講 $\bigcirc$ 張 桂 地取池師木 飞田解調上た石 命富剖 の蘶 b 純

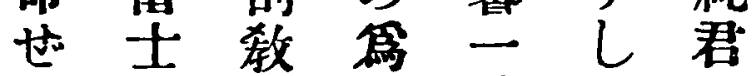
ら郎䇪め君名 礼君江本先は 本於标は月岡 月はてに别限山 十日取出 項 $b$ 醫 九木調張のに學 江住出老如 $\tau$ 專 出血な命々镬阴 發吸 b 長任學 品踦 校 干取醫 5 産 三調本學次科 日の月專た及 歸雼初門 b 婦 䦗め旬學 せ-廣來 校

5 帛岡占

机

目

た 下學

學

噣 託
五 


\section{3 號七十四百二第}

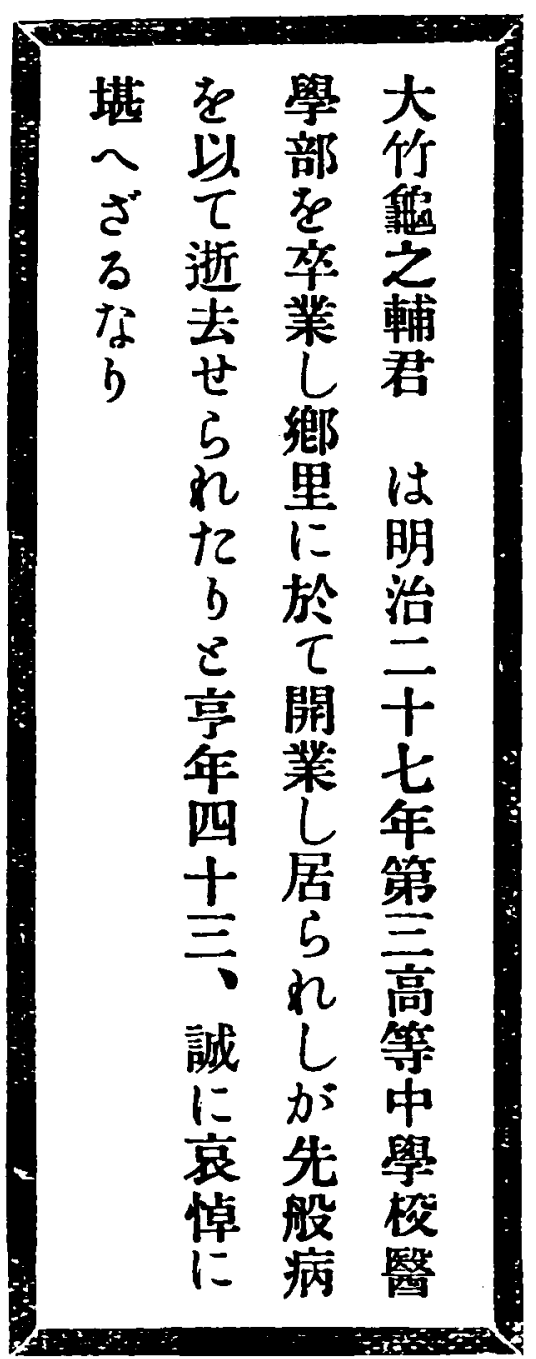

ざ呼ず療に軍して里䂑學古 乃君去病留醫殊し德门部川 な前月院學正功 $\tau$ 島任な武 b途十にしたに外书せ卒雨 有三於彼りよ科古ら業君

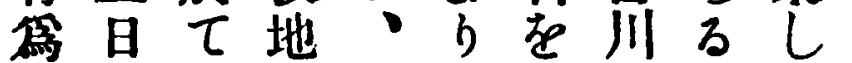

の遂静に四就擔病雨紿君 猡に養於十れ任院來七は る遠して二まし㥀東一明 酿逝つ病年敍又元都年治 しせ 3 四勳日長に志二 七らあ獲月等清合遊願士 空风b昨外蒙 D分學兵三 したし年科 $引$ 日兄し心の年 < $b$ 五專現露台然勤第 逝亭醫月攻にの烳秝严

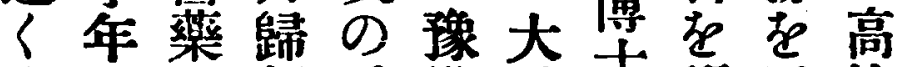
痛四其朝感備戰士研等 恨十效以め陸爭の究へ中 に四子來獨軍に副し䧺學 堪 奏須逸至參院得軍棪

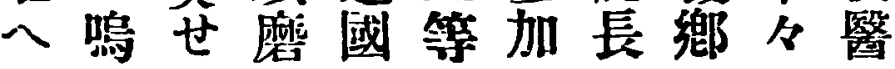

太矢茶木和野堀石石 田澤川村田瀨江原原 太弘茂英勢貫四 男 水一樹次吉茂一 郎

\section{陸○ \\ 軍 學 \\ 軍 生 \\ 分 \\ 學 校 \\ 校 \\ 學 本 \\ 生會}

陸陸 陸陸陸陸陸陸し員

軍軍軍軍軍軍軍軍軍てに

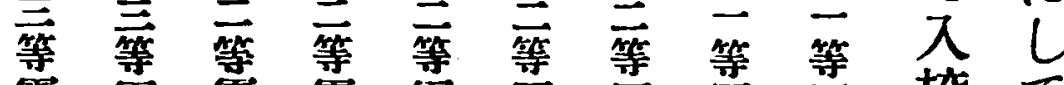

軍寞軍軍审軍营軍校て

醫 醫 醫 醫 醫醫醫 醫せ左

b の

諸

君

は

本

月

H

L
己有日於見狩

謂了逝七睗谷 ふの去静醫猛 心身せ養官君 しをらしこ 为居しは $\tau$ 七 $ら \tau$ 咋 空b蛙年 し君し十阔 く未杪 逝だ天師醫 人春年團學 惜秋点に專 みに假勤門 七富さ稀 學 与名す中校 侖後遂病 活來にる率 餘大本獲業 bに月很し あ偶十里陸 了す仁軍 


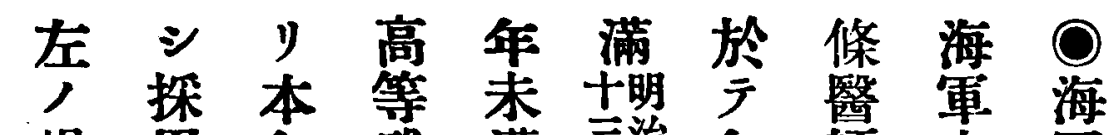
传吳東場角年武䓣年染年師 中軍

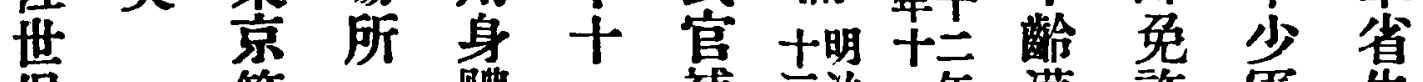

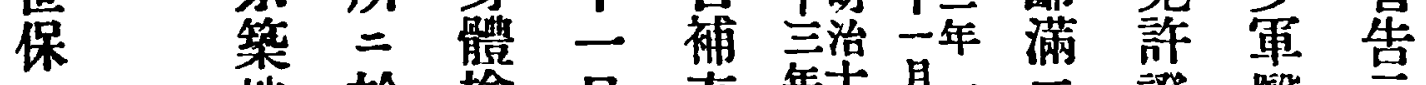

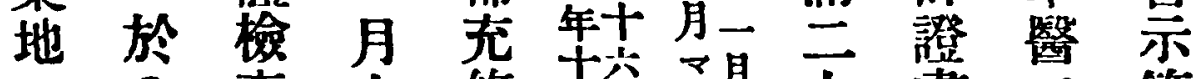

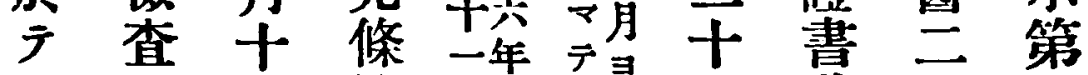

開及五例月二五年若十十

始 學 百立立出同以八五五

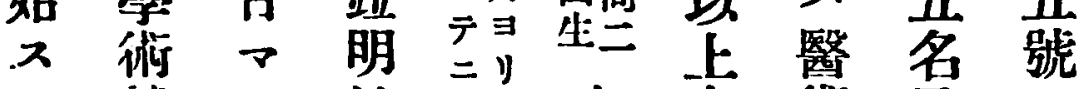

試 广 治出同少中術及

驗 二四生二軍少開海

八海十二醫軍業軍

佐 吳 海

本审 年 $シ$ 候 醫免少 世 海 軍

年省肚 学補二狀軍 十人海出生在 7 醫

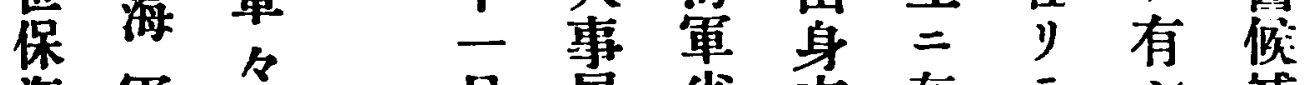
海軍醫名局省志在亏補 病 病學 主長命願、少 主本生 院 院校五出九者八干干名 日 願號 八三三三探 $\exists ス=$ 海十年不用 リ人侬軍，来二攸

陸 陸
軍
等
管
㗨

藤 野 河田 喜 譜 人 佁

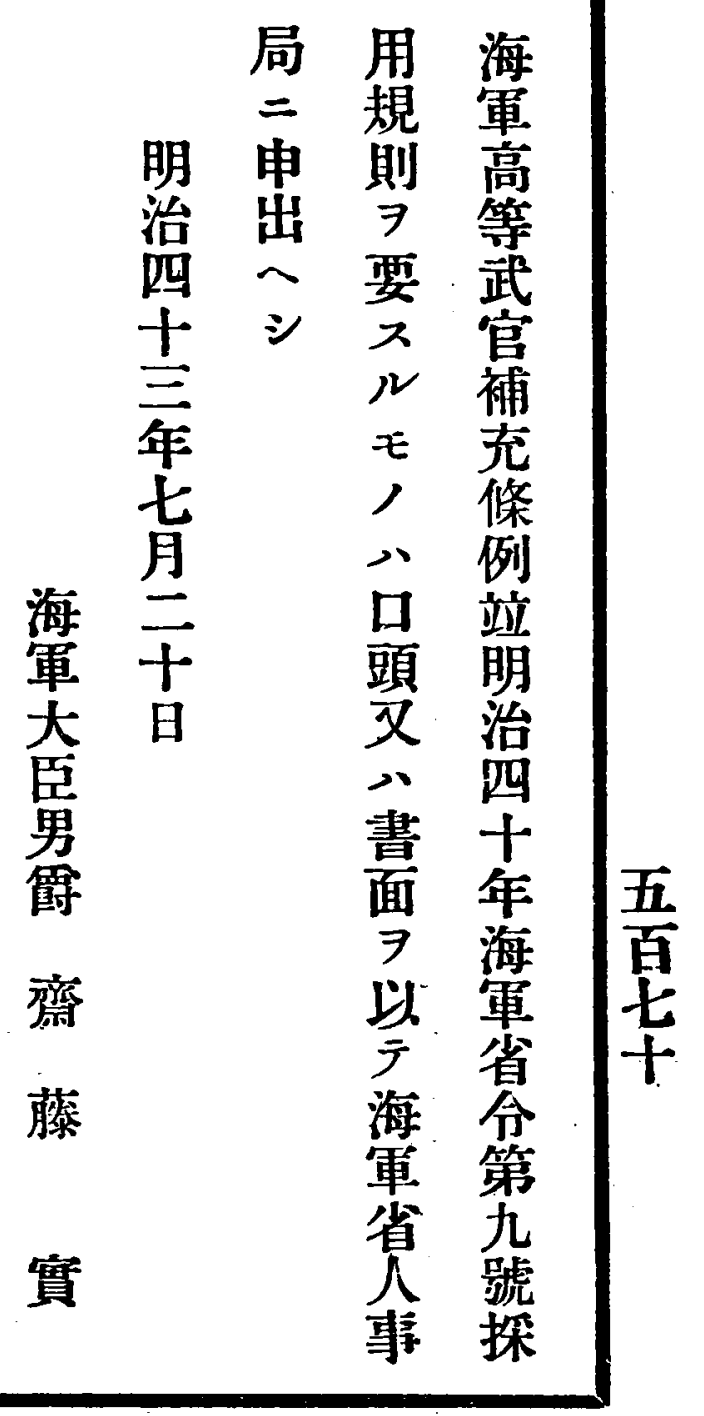

